\title{
A poesia é uma trincheira de guerra
}

Diego Moreira

UFSC

\section{Resumo}

O texto pretende explorar, a partir da leitura de alguns ensaios de Paulo Leminski e dos manifestos de Roberto Piva, a ideia de que a poesia contemporânea assume o caráter de trincheira de guerra. Em textos como "Arte inútil, arte livre?" e "O inutensílio", Leminski defende o fato de que a poesia resiste ao mundo mercadológico justamente por ser um objeto sem nenhuma utilidade prática; por isso, sua importância. Já em Piva, tanto na poesia como na série de manifestos publicados, esparsamente, ao longo da vida, percebe-se a prática de uma poética da transgressão, que funciona como resistência à institucionalização da vida.

Palavras-chave: Paulo Leminski; Roberto Piva; Poesia Brasileira; Trincheira.

\begin{abstract}
The text seeks to explore, through the reading of some essays from Paulo Leminski and manifestos from Roberto Piva, the ideia that contemporary poetry assumes a position of war trench. In texts such as "Arte inútil, arte livre" and "O inutensílio", Leminski defends the fact that poetry resists to marketing world precisely for being an object deprived of practical utility; thus its importance. In his instead, Piva, in poetry as in the series of manifestos sparsely published through his life, presents the reader with the practice of a poetic of transgression, which works as a form of resistance to the institutionalization of life.
\end{abstract}

Keywords: Paulo Leminski; Roberto Piva; Brazilian Poetry; Trench. 
1. PIGLIA, Ricardo. Teoría del complot, 2007, p. 17.

2. Ibidem, p. 17.

3. Cf. HEIDEGGER, Martin. Caminos de bosque, 2010 ps. 199-238.

4. BAUDELAIRE, Charles. Le spleen de Paris, 2003, p. 75.

5. PIGLIA, Ricardo. Teoría del complot, 2007, p. 18-19.
Foi Charles Baudelaire, possivelmente, aquele que primeiro desconfiou do caráter vazio da modernidade. Isto, a crer no retrato baudelairiano oferecido por Walter Benjamin, que lia no poeta francês a mudança de paradigmas sociais operado pelas várias modernizações europeias pós-iluminismo. Há que se lembrar, contudo, que o próprio Baudelaire lia, e trazia para a língua francesa, por sua vez, as narrativas e poemas de outro autor que acabou se tornando uma espécie de pedra-de-toque do conceito de modernidade: Edgar A. Poe.

Se Poe brindou o Ocidente com os meios da narrativa policial, esse movimento não deixa de revelar certas mudanças na forma como as culturas ocidentais encaravam - e encaram - a arte. "En la novela como género, el complot ha sustituido la noción trágica de destino: ciertas fuerzas ocultas definen el mundo social y el sujeto es un instrumento de esas fuerzas que no comprende"1, afirmará Ricardo Piglia em seu Teoría del complot, complementando que "Ya no son los dioses los que deciden la suerte, son fuerzas oscuras las que construyen maquinaciones que definen el funcionamiento secreto de lo real"2.

A alongarmo-nos um pouco mais na questão, encontraremos aqui o eco da pergunta de Heidegger, acerca dos suportes poéticos pós $2^{a}$ Guerra Mundial: a interrogativa, "para que poetas em tempos de penúria?", inspirada por um verso da elegia "Pão e vinho", de Hölderlin, aponta, em primeiro lugar, para uma falta, no caso de Hölderlin, a ausência dos deuses, e é transfigurada por Heidegger de maneira a fazer figurar, a partir dessa fissura, a emergência de uma potência que se encontra, justamente, na linguagem, ou seja, se já não há mais deuses, o que podemos fazer é, precisamente, transferir para a linguagem, nesse caso entendida como poesia, o lugar de sacralização e, ao mesmo tempo, fuga da estética espetacular que transforma a tudo e a todos em ininterrupta diluição ${ }^{3}$. Correndo, evidentemente, todos os riscos que tal sacralização da poesia possa acarretar, uma vez que, desde Baudelaire sabemos que "[...] la plus belle des ruses du diable est de vous persuader qu'il n'existe pas!"4, e aqui podemos afirmar, com segurança, que por Diabo entendemos sociedade capitalista, uma vez que, ainda com Piglia, "La sociedad capitalista no es lo que ella dice que es. Cuando denuncia lo que se supone que funciona mal (la corrupción, el fraude, el delito político), está reforzando la idea de que se trata sólo de anomalías en una lógica que tiene la garantía de su propia autorregulación y de su visibilidad"5.

Nesse sentido, é possível, senão necessário, localizar na iniciativa de vanguarda, melhor dizendo, das vanguardas históricas, uma resposta à crise do liberalismo de fins do século XIX. Onde o liberalismo propunha os princípios de consenso e pacto como reguladores do funcionamento social, as vanguardas 
procuravam questionar esses mecanismos, a partir de uma organização sectária - lembremos o grupo Acéphale de Georges Bataille e companhia -, de intervenções localizadas e secretas, justamente porque as vanguardas perceberam o princípio conspirativo por trás da lógica cultural de produção de valores das obras de arte, assumindo, em consequência, a prática de uma espécie de "guerra de posições" em relação à sociedade. É nesse sentido que, por exemplo, Lúkacs e Adorno renunciarão a uma "função social da arte", ao fazerem da estética da autonomia o fio condutor de suas análises. Entretanto, mesmo nessas análises, está implícita uma função da arte, isto é, que Lúkacs e Adorno não conseguem superar a questão, já que, para eles, Adorno principalmente, a arte é concebida como a esfera social que se separa do cotidiano burguês, uma vez que este está ordenado segundo o princípio de uma racionalidade utilitária, e que a arte, justamente por isso, teria condições de criticá-lo.

Diferentemente de Adorno e Lúkacs, que liam as obras de arte individualmente, encontramos em Herbert Marcuse, no ensaio "Sobre o caráter afirmativo da cultura", uma tentativa de transpor o modelo marxista da crítica dialética para o sistema das objetivações artísticas. Marcuse apresenta a afirmação global da função da arte na sociedade burguesa, como constituída a partir de princípios contraditórios: por um lado, a arte mostra "verdades esquecidas", protestando contra o fato de tais verdades não mais terem valor no mundo; por outro, as verdades são desatualizadas através do meio da aparência estética que, por sua vez, estabiliza as mesmas condições sociais contra as quais protesta $^{6}$. Praticamente, um exemplo disso é o de Duchamp e de seus usos subsequentes: se, por um lado, o ato de colocar um urinol dentro de um museu gritava contra a institucionalização da arte, queria implodir aquela estrutura, ao mesmo tempo as tentativas posteriores a Duchamp mostram, por parte dos artistas, o intuito de estarem dentro do museu, de serem incluídos nesse sistema globalizante chamado arte. E aqui o modelo de Marcuse se mostra importante, uma vez que mostra que as obras de arte não são recebidas individualmente, mas a partir de um marco de condições institucionais, de dentro das quais sua função, de maneira geral, é estabelecida.

Em Teoria da vanguarda, Peter Bürger assinala, a partir da relação entre vanguardas históricas e teoria crítica, os motivos que levaram ao fracasso das primeiras. De acordo com ele,

No fracasso do ataque dos movimentos históricos de vanguarda à instituição arte, três momentos de cruzam: 1. o projeto historicamente necessário de uma superação da arte na práxis de vida, que é, em igual medida, resultado da lógica de desenvolvimento da arte (o problema do esteticismo), como dinâmica do desenvolvimento da sociedade
6. Cf. MARCUSE, Herbert.

"Über den afirmativen Charakter der Kultur”, 1968, ps. 56-101. 
7. BÜRGER, Peter. Teoria da vanguarda, 2012, p. 17.

8. ALIGHIERI, Dante. A Divina Comédia: Inferno, 1998, p. 26.

9. Ibidem, p. 26-27. burguesa (crise desta sociedade na Primeira Guerra Mundial); 2. a impossibilidade de realizar tal projeto sob as condições sociais dadas; 3 . e, finalmente, a capacidade de resistência da instituição, cuja superação, historicamente, parecia estar na ordem do dia. $\mathrm{O}$ fracasso do projeto vanguardista não significa um retrocesso às condições de partida; antes, traz como consequência uma transformação da instituição arte, que talvez possa assim ser formulada: a instituição arte continua existindo, mas como instituição abalada (o "Irrealis", em Adorno, dá conta dessa formulação). As categorias da estética idealista não foram simplesmente tornadas válidas mais uma vez - elas perduram como categorias destituídas de valor [...] Algo mais mudou desde os movimentos históricos de vanguarda: se o esteticismo ainda podia responder de forma relativamente concisa à questão sobre o que é a arte, isso agora já não confere mais; tal questão é lançada hoje aos próprios produtores. Se estes, dentro da arte institucionalizada como autônoma, precisavam estar sempre a determinar a sua relação com a instituição, hoje, antes de mais nada, veem-se na necessidade de, por meio do seu trabalho, dar provas da possibilidade da arte. Enquanto o mercado da arte se transforma cada vez mais em campo de especulação do capital internacional, virtualiza-se o marco normativo dentro do qual trabalha o artista individual. Aquilo que hoje se discute sob o infeliz verbete da "pós-modernidade" não passa de um velho problema da modernidade, evocador da famosa-famigerada proposição hegeliana do fim da arte: a sociedade burguesa não possui uma arte que lhe seja genuína, mas - contra Hegel e com Adorno, seria o caso de adicionar um complemento à proposição - precisa dela. ${ }^{7}$

É fácil compreender aqui a polêmica formada em torno do livro de Bürger: publicado três anos após a morte de Lúkacs, em 1974, busca "salvar", encobrindo-o com o escudo da teoria crítica, o surrealismo, que a essa altura já estava sendo apropriado pelos pós-estruturalistas, que o liam desde Sade. De todo modo, a partir da afirmação de que quem deve responder sobre "o que é arte" hoje são os próprios produtores, não deixa de se aproximar, por exemplo, de Foucault e Barthes, já que este último, inclusive, escrevia um ano antes sobre os semiogramas de André Masson, companheiro de Georges Bataille na experiência Acéphale, e encontrava na obra de Masson não poucas aproximações com a "Teoria do texto", que ele e Kristeva desenvolviam nos anos 1970.

No início de A Divina Comédia, Inferno, Dante Alighieri, perdido em um pesadelo, presumidamente por se haver afastado da virtude em Cristo, encontra-se cercado por uma selva apavorante e, descendo por uma encosta, é impedido de continuar, consecutivamente, por três feras que lhe impedem a passagem: "uma onça ligeira e desenvolta", um "leão / que parecia que contra mim viesse" e, por último, "uma loba, de cobiça ansiosa 
/ em sua torpe magreza carregada" ${ }^{\text {". }}$. Não se trata de qualquer pesadelo. Não apenas por se haver tornado uma das maiores manifestações poéticas do Ocidente em todos os tempos, mas, igualmente, porque, como nos alerta o poeta ainda no Canto I, essa mesma "selva selvagem e áspera e forte" poeta "No meio do caminho de nossa vida"12, isto é, justamente nesse período de passagem entre os ímpetos revolucionários da adolescência e a experiência sisuda trazida pela velhice. Alguns séculos depois de Dante, Carlos Drummond de Andrade escreverá que "No meio do caminho, tinha uma pedra"13. Já Augusto dos Anjos, no poema "As cismas do destino", caminha pela "Ponte Buarque de Macedo / Indo em direção à casa do Agra / Assombrado com a minha sombra magra / Pensava no Destino, e tinha medo!"14. Se viajarmos ainda mais longe, a Ilíada narra os acontecimentos do $10^{\circ}$ ano da guerra de Troia, e a Odisseia, o retorno de Ulisses a Ítaca, vinte anos decorridos dessa mesma guerra. O que nos permite, contudo, agrupar poemas e poetas separados cronológica e estilisticamente é justamente a ideia, presente em seus textos, de que a poesia surge como esse "meio de caminho", encruzilhada de linguagem, como a ponte que configura-se como um ponto de ligação entre dois locais distintos mas que, por si só, não pode ser vista como uma finalidade ou o objetivo último de uma trajetória. Para além da ideia de ponto de ligação, há igualmente a ideia de algo colocado no meio, colocado entre, espécie de obstáculo entre aquilo que se quer defender e o que não se quer deixar passar. Na guerra, isso se chama trincheira.

Em 1888, Raul Pompéia publica, na Gazeta de Notícias, a crônica "Glória Latente". Trata-se do relato de um poeta que, tomado por um impulso criativo, decide organizar, a partir da palavra poética, suas divagações, na forma de um poema dividido em três cantos, os quais o poeta define da seguinte maneira:

O primeiro canto celebraria a Vontade e o Amor, inteligência e instinto, as feições primordiais da existência poeticamente delimitadas e o encontro destas energias, distintas, confundindo-se como sexos, ou divergindo violentamente para promover os dramas da natureza e da humanidade [...] O segundo canto resumiria a construção histórica da Vontade: sociedade, impérios, as corrupções, as guerras, acabando pelo espetáculo de Roma espavorida, estalando as calçadas de mármore das praças sob o galope da cavalaria dos bárbaros [...] O canto terceiro seria a notícia épica dos fatos do Amor, religiões, com o argumento das filosofias, perseguições, martírios, num quadro da Idade-Média. Serviria de remate à agonia do último Cruzado em São João d'Acre, velho, esquecido desde muito da sua dama, negando Deus, prevendo e lamentando um futuro a chegar em que a Vontade predominaria inteiramente, vestida na frase de todos os disfarces, saudando enfim a Morte, a terrível
10. Ibidem, p. 27.

11. Ibidem, p. 25.

12. Ibidem, p. 25.

13. ANDRADE, Carlos

Drummond de. Alguma poesia, 2013, p. 36.

14. ANJOS, Augusto dos. Eu e outras poesias, 2010, p. 22. 
15. POMPÉIA, Raul. "Glória Latente", 2013, p. 82-84.

16. Ibidem, p. 83.

17. Cf. NETO, João Cabral de Melo. Prosa, 1998, p. 51-70.

18. Cf. SCHILLER, Friedrich. Poesia ingênua e sentimental, 1991. amiga e conselheira, que havia de sugerir um dia a verdade da vida como sugeriu as crenças vácuas e as meditações inanes... ${ }^{15}$

De todo modo, após fornecer ao leitor os três motes que regerão a composição do poema, o autor parece esbarrar contra o muro da incomunicabilidade da poesia, como ratifica neste trecho da crônica:

Palavra?... Sim, o veículo da vaidade de que o escritor depende, palavra, o mesmo vil instrumento das permutas do interesse e do apetite.

Uma dúvida de repugnância paralisou-lhe a pena.

- Escrever: formular, comunicar. Mas que pretendemos dos outros? Aplauso? A arte que vive do aplauso rebaixa-se, prostitui-se; as chamas ardem para cima. Critério? A arte que não tem apoio na convicção própria da força sucumbe; a hesitação atrofia e anula; a arte forte cresce de si mesmo, organicamente. ${ }^{16}$

Pompéia procede, em "Glória Latente", de forma semelhante ao já citado Edgar A. Poe em "Psychology of composition", mostrando que a poesia, para ele como para o escritor norte-americano, não é tanto um processo regido pela pura inspiração, pelo sopro divino da Musa, do Gênio ou de Deus, quanto um processo intelectual que conduz à junção entre forma e conteúdo.

Semelhante pensamento acerca do processo artístico - ou dos processos do artista - possui o poeta paranaense Paulo Leminski. Levando em conta, para além e ao mesmo tempo em conjunto com sua poesia, a série de ensaios que escreveu entre os anos 1970-1980, encontraremos um poeta preocupado com alguns dos grandes problemas que a modernidade industrial e, mais ainda, o capitalismo tardio e o neoliberalismo consequente, legaram aos artistas ocidentais. Talvez o maior desses problemas se caracterize como certa perda, justamente, do princípio de comunicação atribuído à poesia desde a Antiguidade Clássica. Contudo, Leminski não foi o primeiro a apontar para essa falência, nem mesmo no contexto brasileiro. João Cabral de Melo Neto, em um texto hoje canônico, "Poesia e composição", que surge como uma conferência pronunciada na Biblioteca Municipal de São Paulo, em 1952, comenta a situação da poesia moderna, especificamente do segundo pós-guerra, a partir de uma oposição entre dois tipos de poetas, o "inspirado" e o "construtivo" ". Cabe lembrar que essa oposição não é nenhuma novidade na tradição poética ocidental, e que remonta, em última análise, às formulações de Friedrich Schiller em "Poesia ingênua e sentimental" ". Novidade trazida pelo poeta pernambucano em seu texto, esta sim, é a ideia do caráter singular da 
modernidade. De acordo com ele, diferentemente do que ocorria nas que chamou "épocas de equilíbrio", a modernidade, para a poesia, dá-se a partir da perda daquela que seria a contraparte do escritor, ou seja, o leitor, e que, a partir daí, a poesia já não possuiria mais o desígnio de comunicação.

Dois anos mais tarde, o tema da morte da função comunicativa da poesia moderna foi alvo de outra conferência de João Cabral, apresentada no Congresso de Poesia de São Paulo. Em "Da função moderna da poesia", contudo, o poeta mostra certo desprezo pelo "poema moderno", para ele definido como

[...] esse híbrido de monólogo interior e discurso de praça, de diário íntimo e de declaração de princípios, de balbucio e de hermenêutica filosófica, monotonamente linear e sem estrutura discursiva ou desenvolvimento melódico, escrito quase sempre na primeira pessoa e usado indiferentemente para qualquer espécie de mensagem que o seu autor pretenda enviar. ${ }^{19}$

Em "Poesia e composição", um dos maiores apelos de Cabral era o de que se pudesse, de alguma forma, fazer com que a poesia voltasse a ter uma "função" para a vida do leitor moderno, que ela pudesse se adequar aos novos meios de comunicação de massa, tais quais o rádio, o cinema e a emergente televisão. Não se tratava, evidentemente, de um projeto como o da poesia revolucionária russa, muito mais pedagógico que estético, mas sim de um tipo de intervenção que pudesse retirar a poesia do automatismo solipsista que vinha sendo, segundo Cabral, sua maior característica, desde 1945 até então.

A primeira resposta aos apelos de Cabral - ou pelo menos era o que se acreditava à época - veio em 1958, quando os irmãos Haroldo e Augusto de Campos e Décio Pignatari publicaram, no $n^{\circ} 4$ da revista Noigandres, o "Plano piloto para poesia concreta". Nesse manifesto, cujo título inspira-se no do projeto de criação de Brasília, lê-se logo à primeira linha que a poesia concreta é o "produto de uma evolução crítica de formas, dando por encerrado o ciclo histórico do verso" ${ }^{20}$. De todo modo, o projeto concreto já dava mostras, antes mesmo da publicação do plano piloto, de que seu grande objetivo - adequar a poesia à linguagem da publicidade e propaganda, acabar com a forma verso, comunicar para ampliar o alcance do fenômeno poema não seria alcançado, embora seus ecos tenham sido sentidos por mais de uma geração da poesia brasileira, e ainda se façam sentir contemporaneamente.

É ali, no contexto da poesia concreta, que surge Paulo Leminski, ao ter seus primeiros poemas publicados na revista Invenção, em 1964. Tributário dos concretos, Leminski não se mostrou, todavia, submisso a eles, transitando entre a cultura
19. NETO, João Cabral de Melo. Prosa, 1998, p. 101.

20. CAMPOS, Augusto de; CAMPOS, Haroldo de; PIGNATARI, Décio. Noigandres 4, 1958, [s. p.]. 
21. Todos os ensaios de Paulo Leminski citados neste trabalho foram retirados de LEMINSKI, Paulo. Ensaios e anseios crípticos. $2^{a}$ ed. ampliada. Campinas: Editora da Unicamp, 2012. O diretor da editora da Unicamp, à época, era Paulo Franchetti, que em seu texto "Paulo Leminski e o haicai" critica duramente Leminski, por haver feito aquilo que Franchetti classifica como uma facilitação do haicai da tradição de Bashô. Nos termos de Franchetti: "O seu haicai [de Leminski] configurou-se como 'alternativo', no sentido que essa palavra tinha nos anos 70 e 80 no Brasil. Para assim configurá-lo, o que Leminski acrescentou ao haicai de Millôr foi um discurso paralelo sobre a poesia como expressão direta e produto de uma experiência não necessariamente - ou talvez fosse melhor dizer, preferentemente - racionalizada ou racional. [...] O sucesso foi grande, mas o preço foi apagarse rapidamente aquilo mesmo que constituía a singularidade do haicai entre as formas poéticas. Desaparecia o haicai tal como disseminado no Ocidente por Blyth e Suzuki, borrando-se os seus traços mais característicos, que o definiam como gênero e promoviam o seu lugar de diferença em relação à poesia ocidental. [...] Lidos hoje, seus tercetos ressentem-se do desaparecimento do entorno crítico e da ação pública poeta [sic], que criaram as condições para que o haicai se tornasse moda avassaladora. [...] Por conta do sucesso do haicai de Leminski, outras tradições brasileiras que interpelavam esse tipo de poesia japonesa ficaram à sombra. Ao mesmo tempo, a desconfiança crítica em relação ao que haveria de facilitação e desinteresse no haicai, tal como definido por Leminski, passou a orientar a recepção crítica do gênero. Hoje, de fato, esse 'haicai' é um pasto aberto à mediocridade erudita e o universo popular da cultura de massa sem maiores dificuldades. Desde a publicação de seu primeiro livro que, dizem, não é de poesia, o Catatau, de 1975, Leminski sempre se mostrou preocupado com as questões que assombraram Cabral, ou seja, como fazer poesia em um mundo cada vez mais utilitarista? A investigação aponta para um poeta que, através de seus poemas mas, igualmente, de seus ensaios, vê na poesia não um ritual comunicativo entre enunciador e receptor, porém, muito mais que isso, uma instância combativa a partir da qual o poeta se refugia para bater de volta no mundo que diariamente o agride. Basta ler, por exemplo, o ensaio "Arte inútil, arte livre?"21.

A curiosa ideia de que a arte não está a serviço de nada a não ser de si mesma é relativamente recente. Data do romantismo europeu do século XIX, apogeu da I ${ }^{a}$ Revolução Industrial e da hegemonia burguesa, momento em que o artista se torna um desempregado crônico.

Arte e artesanato. A indústria veio para substituí-lo.

Sem função social mas ainda cheia de sua própria importância, a arte, entre horrorizada e fascinada, volta-se contra o mundo utilitário que a cerca, negando-o, criticando-o, como um não objeto feito de antimatéria. ${ }^{22}$

Após essa constatação inicial, Leminski localiza o nascimento da doutrina da "arte pela arte" na França, no século XIX, e a contrapõe a um ideal medieval de arte, uma vez que, de acordo com seu texto,

Uma arte, uma literatura in-útil: nenhuma ideia poderia ser mais estranha à Idade Média católica, herdeira das concepções greco-latinas sobre o duplo papel da arte: "delectare", "agradar", e "docere", "instruir".

Para um europeu letrado da Idade Média (quase sempre um clérigo) [...] a obra literária tem deveres morais. Não há lugar para uma obra blasfema, sacrílega, iconoclasta, dissolvente, corruptora.

A obra de arte é a expressão de uma norma. Não um gesto criminoso. $^{23}$

Para Leminski, nesse texto, o poeta, contemporaneamente, é entendido como "uma consciência problemática expressando em palavras seus conflitos" 24 . É uma definição simplificadora, pacificadora até, mas que está de acordo com o projeto leminskiano de uma poética que pudesse, de certa maneira, colocar-se na linha de frente do combate contra o progressivo ocaso da poesia brasileira dos anos 1960-1970. Como "consciência problemática", o poeta não pode ser facilmente enquadrado nas engrenagens da máquina social utilitária que o sufoca. Ao mesmo tempo, está em permanente "conflito" com o mundo, uma vez que, como não tem mais nenhum compromisso com qual- 
quer programa ideológico pré-definido, como a representação do divino (a exemplo de Dante e Milton) ou as qualidades do indivíduo enquanto representante de uma ideia de nação (como Homero e Virgílio), encontra-se "no mato sem cachorro"25.

Seguindo com a sua proposição de um choque entre tempos, em "Arte inútil, arte livre?”, Leminski afirma que

\begin{abstract}
No mundo burguês, a obra de arte só pode ser duas coisas: ornamento e mercadoria. Um afresco renascentista na parede de uma igreja é um complexo composto ideológico, pulsando de tensões morais e intenções de envolvimento coletivo. Um quadro de Manabu Mabe na sala de um banqueiro é apenas um complemento do tapete e do padrão dos sofás. A burguesia saudou a liberdade formal da arte moderna, comprando-a. [...] Ao ouvir falar em arte moderna, o burguês puxa o talão de cheques. ${ }^{26}$
\end{abstract}

Para, com isso, a partir de uma diferenciação entre as artes plásticas e a literatura, afirmar que esta "resistiu com particular vigor" 27 ao processo de comercialização ao qual as outras artes sucumbiram. Isto porque as artes plásticas, feitas com ícones, se localizariam num campo diferente do da literatura, que é feita com palavras, isto é, símbolos, "que o poeta, alquimista, tenta transformar em ícones"28. Nesse sentido, Leminski não incorre no erro de pensar a literatura como destituída de uma iconoclastia própria, da qual o Barroco seria, por exemplo, uma experiência evidente. Não à toa, a empreitada leminskiana no Catatau caracteriza-se como uma espécie de retomada e reconfiguração de ícones, a partir de um olhar que devora o outro, um outro que é, antes de tudo, o dominador, ou seja, um dos representantes máximos do pensamento racional advindos da matriz de referência cultural, a Europa. Desse modo, é a partir da profanação do ícone, René Descartes, que o universo, não gratuitamente chamado "neobarroco", do Catatau, se configura. Consequentemente, partindo do princípio de que o combate entre o poeta e o mundo está em curso, a recusa do primeiro em fazer qualquer tipo de concessão àqueles que, porventura, venham a manter contato com seu texto, se justifica já na primeira proposição da obra: "Me nego a ministrar clareiras para a inteligência deste catatau que, por oito anos, agora, passou muito bem sem mapas. Virem-se"29.

Cabe lembrar aqui o já mítico processo de escritura do Catatau, uma vez que nos parece uma concretização prática do hoje tão falado zen leminskiano. A crer na história oficial, em meados dos anos 1960 Leminski era professor de história em cursos pré-vestibulares. No decorrer de uma aula em que discutia o tópico das "invasões holandesas", ocorreu-lhe a estranha e ainda enxameiam, em toda parte, os sub-leminskis. É já lugar comum dizer que Leminski não pode responder pela legião de fãs que baratearam as suas propostas e recursos. Mas responde pela banalização do nome, por meio da prática, que não soube, nesse caso, - como soube nos melhores momentos da sua poesia - dosar a facilidade como elemento de adulação e conquista do público". FRANCHETTI, Paulo. "Paulo Leminski e o haicai", 2010, p. 51-74. Esse texto, originalmente publicado no ano de 2010, foi republicado, no mesmo ano, no website da revista Sibila, publicação um tanto conservadora no que se refere à poesia contemporânea. Como diretor da editora da Unicamp, Franchetti não deve ter ficado muito feliz em ser obrigado a publicar os ensaios de Leminski. Realizou, contudo, sua pequena vingança: todos os ensaios publicados nesse volume encontram-se sem nenhuma referência quanto às datas e locais das publicações originais, diferentemente das edições mais modestas publicadas pelo Pólo Editorial do Paraná, de quem a editora Unicamp absorveu os textos, incluindo outros mais. Da mesma forma, não há nada à guisa de introdução, prefácio, estudo crítico, posfácio, ou qualquer coisa que o valha.

22. LEMINSKI, Paulo. Ensaios e anseios crípticos, 2012, p. 41.

23. Ibidem, p. 42.

24. Ibidem, p. 43.

25. Ibidem, p. 43.

26. Ibidem, p. 45.

27. Ibidem, p. 45.

28. Ibidem, p. 45.

29. LEMINSKI, Paulo. Catatau: um romance-ideia. Curitiba, Travessa dos Editores, 2004, p. 10. Essa nota consta apenas na presente edição, tendo sido suprimida, por exemplo, na edição de 2010 da Editora Iluminuras. 
30. Cf. VAZ, Toninho. O bandido que sabia latim, 2001.

31. FAUSTINO, Mário. "Revendo Jorge de Lima”, 2013, p. 628. ideia: e se René Descartes tivesse deixado a Europa e vindo aportar junto aos holandeses no litoral de Pernambuco? Sabe-se das relações de Descartes com a família de Maurício de Nassau. A hipótese estava dada, e Leminski a desenvolveu no conto "Descartes com lentes". Três anos depois, sob o pseudônimo de "Kung", inscreveu o conto num concurso em Curitiba. Por conta de um erro gráfico do júri, não se consagrou vencedor, o prêmio sendo entregue a um tal "Kurt". O fato foi revelado quase vinte anos depois por Fausto Cunha, um dos jurados do concurso $^{30}$. Decepcionado e irritado por não haver recebido o prêmio, o poeta decide então "vingar-se" da miopia do júri, transformando o conto em um "romance-ideia" de composição ainda mais complexa. O processo de feitura do livro, de acordo com familiares e amigos, dá conta de que Leminski andaria com um calhamaço de folhas manuscritas embaixo do braço, levando o texto a qualquer lugar que fosse, registrando ali frases soltas que ouvia nas ruas, bares, ambientes de trabalho, assim costurando a intrincada rede de discursos que se interpenetram no Catatau.

O surgimento de uma obra de volume e densidade tão grandiosas, na literatura brasileira, pertence ao mesmo grupo em que se enquadram os sertões de Euclides e Rosa, e a Invenção de Orfeu de Jorge de Lima, muito embora o Catatau seja mais comumente associado às Galáxias de Haroldo de Campos. Sobre o texto de Leminski, pode-se concordar com a proposição de Mário Faustino, que, ao comentar a Invenção de Orfeu, dispara: "A simples tentativa, nesta terra e nesta língua de tímidos e de preguiçosos, é já elogiável"31.

De igual modo, essa espécie de iluminação que leva o poeta a imaginar uma perversão da história, esse instante de pensamento a partir do qual se desenha um universo de ressignificações do mundo e, por consequência, da linguagem, não é senão uma das manifestações do zen que se configurou como uma das obsessões da vida e da obra leminskianas. Por isso, inclusive, a recusa por "ministrar clareiras para a inteligência" da obra, uma vez que é justamente a partir de uma negação radical da mimese, da representação racional da realidade, que ela funciona.

Não se trata, evidentemente, de relegar ao Gênio ou à Musa a feitura do Catatau. Se, ao contrário de Edgar A. Poe ou Raul Pompéia, Leminski se nega a fornecer a sua "psicologia da composição" do Catatau, é porque o processo por ele adotado aponta para outra via, que não se reduz à pura inspiração, muito menos à aplicada construção, para retomar os termos de João Cabral de Melo Neto; trata-se, diferentemente, de um processo de desmistificação da racionalidade (que ataca Descartes, um dos santos mais cultuados pelo Iluminismo), que a faça ceder lugar aos vórtices de um pensamento selvagem, antropófago, 
que é, por vezes, descuidado em seu hermetismo, em seus “caprichos e relaxos".

A partir disso, compreende-se melhor o fato de que a poesia, ecoando o que diz Leminski em "Arte inútil, arte livre?", apresente enorme dificuldade em transformar-se em mercadoria, e que ao mesmo tempo seja, enfim, "a última trincheira onde a arte se defende das tentações de virar ornamento e mercadoria, tentações a que tantas artes sucumbiram prazerosamente" 32 . Assim sendo, a única configuração em que a poesia se torna possível, no mundo contemporâneo, é a de uma empreitada guerrilheira, uma vez que "a arte está em conflito direto com o mundo. A melhor arte do século XX é um gesto contra o mundo que a rodeia. Uma negatividade" 33 .

Portanto, não é de se admirar que, em "Poesia: vende-se", outro ensaio, Leminski defina, no patamar nacional, o modernismo paulista como o ponto de franca abertura do combate. Como afirma, no texto em questão,

No início do século $[\mathrm{XX}]$, não, você pisava em terreno seguro.

Poesia era aquela caixinha de bombons chamada soneto, um pedaço bem cortado de frases enfeitadas, que emitia sempre o mesmo plim, como um canário na gaiola ou uma caixinha de música.

Nos tempos de Bilac, você sabia o que comprava.

Nos anos 1920, os modernistas de São Paulo, influenciados por doutrinas alienígenas, dinamitaram a central elétrica. E, em lugar do verbo agradar, passaram a conjugar o verbo agredir. ${ }^{34}$

E a agressão, ao menos a partir do século $\mathrm{XX}$, passa necessariamente por uma recusa em submeter-se à ordem utilitária do mundo da produção, do capital financeiro e das multinacionais que operam sob o signo falacioso da "globalização". Em outras palavras, por uma recusa da arte, mais especificamente da poesia, em tornar-se algo "útil". É a ideia central de Leminski nesses ensaios, inclusive no mais batailleano de todos, "O inutensílio", em que afirma:

O amor. A amizade. O convívio. O júbilo do gol. A festa. A embriaguez. A poesia. A rebeldia. Os estados de graça. A possessão diabólica. A plenitude da carne. O orgasmo.

$[\ldots]$

Fazemos as coisas úteis para ter acesso a estes dons absolutos e finais. A luta do trabalhador por melhores condições de vida é, no fundo, luta pelo acesso a estes bens, brilhando além dos horizontes estreitos do útil, do prático e do lucro.

Coisas inúteis (ou "in-úteis") são a própria finalidade da vida..$^{35}$

Em "A noção de dispêndio", texto originalmente publicado no $\mathrm{N}^{\circ} 7$ da revista La critique sociale, em 1933, mesmo ano
32. LEMINSKI, Paulo. Ensaios e anseios crípticos, 2012, p. 46 [grifo nosso].

33. Ibidem, p. 47.
35. Ibidem, p. 86. 
em que, na Alemanha do $3^{\circ}$ Reich, Adolf Hitler ascendia ao poder, Georges Bataille formula, de forma resumida, os pontos de ancoragem que servirão de base à sua teoria econômica, posteriormente estendida em livros como $A$ parte maldita, $O$ erotismo e Teoria da religião. Partindo da ideia de que o luxo e o gasto devem ser - ao contrário do acúmulo - os objetivos primeiros da atividade social humana, o escritor e filósofo francês afirma:

Não existe, com efeito, qualquer meio correto, tendo em vista o conjunto mais ou menos divergente das concepções atuais, que permita definir o que é útil aos homens. Essa lacuna é suficientemente indicada pelo fato de que é constantemente necessário recorrer, do modo mais injustificável, a princípios que se procura situar para além do útil e do prazer: a honra e o dever são hipocritamente empregados em combinações de interesse pecuniário e, sem falar de Deus, o Espíito serve para mascarar a desordem intelectual das poucas pessoas que se recusam a aceitar um sistema fechado.

No entanto, a prática corrente não se embaraça com essas dificuldades elementares, e a consciência comum parece, à primeira vista, poder opor apenas reservas verbais ao princípio de utilidade clássica, ou seja, da utilidade que se pretende material. Esta tem teoricamente como finalidade o prazer - mas somente sob uma forma moderada, pois o prazer violento é tido como patológico - e se deixa limitar, por um lado, à aquisição (praticamente à produção) e à conservação dos bens e, por outro, à reprodução e à conservação das vidas humanas.

$[\cdots]$

No conjunto, porém, qualquer julgamento geral sobre a atividade social subentende o princípio de que todo esforço particular deve ser redutível, para ser válido, às necessidades fundamentais da produção e da conservação. $\mathrm{O}$ prazer, quer se trate de arte, de desregramento admitido ou de jogo, é definitivamente reduzido, nas representações intelectuais que tem curso, a uma concessão, ou seja, a um descanso cujo papel seria subsidiário. A parte mais apreciável da vida é dada como a condição - às vezes mesmo como a condição lamentável - da atividade social produtiva.

$[\ldots]$

A esse respeito, é triste dizer que a bumanidade consciente permaneceu menor: ela se reconhece o direito de adquirir, de conservar ou de consumir racionalmente, mas exclui, em

36. BATAILLE, Georges. $A$ parte maldita - precedida de "A noção de dispêndio”, 2013, p. $19-20$.

\section{princípio, o dispêndio improdutivo. ${ }^{36}$}

$\mathrm{E}$, mais adiante, ao falar especificamente sobre a arte, Bataille diferencia a relação de dispêndio em duas categorias: a do dispêndio "real" - a qual pertencem a arquitetura, a música e a dança - e a do dispêndio "simbólico" - que engloba a escultura e a pintura, o teatro e a literatura. Sobre as duas últimas categorias, formula: 
Em sua forma maior, a literatura e o teatro, que constituem a segunda categoria, provocam a angústia e o horror por meio de representações simbólicas da perda trágica (desgraça ou morte); sob sua forma menor, provocam o riso por meio de representações cuja estrutura é análoga, mas que excluem certos elementos de sedução. ${ }^{37}$

Mais especificamente, sobre a poesia, afirma:

O termo poesia, que se aplica às formas menos degradadas, menos intelectualizadas da expressão de um estado de perda, pode ser considerado como sinônimo de dispêndio: significa, com efeito, do modo mais preciso, criação por meio da perda. Seu sentido, portanto, é vizinho do de sacrifício. ${ }^{38}$

Sacrifício que, ainda de acordo com Bataille, "não é senão outra coisa, no sentido etimológico da palavra, que não a produção de coisas sagradas" 39 .

Giorgio Agamben, em parte retomando o fio da discussão de Bataille, aponta para a fratura existente na modernidade a partir do século XIX, fratura que, ao invés de funcionar como passagem, configura-se, de maneira diversa, como interdição da passagem entre o político e o sagrado ${ }^{40}$. A partir dessa interdição, a modernidade deixa a esfera do mito, ou do sacro, e adentra a realidade do "insacrificável”, uma vez que, negando-se a destruir a si mesma, cria, por sua vez, um inimigo interno, perpetuamente em vias de ser destruído, e configura-se, assim, como um lugar de mote, cujo centro está irreparavelmente vazio. Mas há modos de a modernidade declinar de si mesma. De acordo com Scramim,

Os românticos e os simbolistas ofereceram à literatura esse poder de declinar, no entanto, os românticos franceses pretendiam inaugurar um novo mundo, enquanto que os simbolistas, que também se insurgem como revolucionários, têm como objeto da sua revolta o conceito mesmo de literatura. $^{41}$

Ou seja, a arte, mais precisamente a poesia, é a instância em que se denunciará, em última análise, o fato de que o rei está nu.

De todo modo, se para Paulo Leminski o combate exigia uma postura de equilíbrio entre aquilo que encarava como facilitações ou concessões feitas ao leitor casual e a erudição daqueles já familiarizados com a tradição poética ocidental, houve outro poeta, contemporâneo a Leminski, que assumiu uma postura de quase que absoluta recusa pelas alternativas poéticas da época, tentando estabelecer, através de sua poesia, uma terceira via em relação ao contexto poético brasileiro dos anos 19601970. Trata-se de Roberto Piva.
37. Ibidem, p. 23.

38. Ibidem, p. 23.

39. Ibidem, p. 22.

40. Cf. AGAMBEN, Giorgio.

Homo sacer: o poder soberano e a vida nua I, 2002.

41. SCRAMIM, Susana. "Paulo Leminski e o simbolismo", 2010, p. 218. 
42. HOLLANDA, Heloísa

Buarque de. Impressões de viagem:

CPC, vanguarda e desbunde 1960/70, 2004, p. 22.

43. COHN, Sérgio (org.). Encontros: Roberto Piva, 2007, p. 102.
De acordo com o CPC - Centro Popular de Cultura, criado em 1961, no Rio de Janeiro, por Carlos Diegues, Oduvaldo Viana Filho, Leon Hirszman e Carlos Estevam Martins - os artistas e intelectuais brasileiros da época estariam distribuídos (termo de Heloísa Buarque de Hollanda) em três alternativas distintas: "O conformismo, ou inconformismo, ou a atitude revolucionária consequente" 42 . A proposta do CPC era radicalmente oposta, ao menos teoricamente, da dos concretos: visavam munir intelectualmente a população brasileira - utilizando-se para isso de uma arte popular e engajada politicamente -, a fim de realizar por aqui o mesmo tipo de revolução que se realizara em Cuba. Portanto não se admira que um poeta da importância de Piva acabasse sendo relegado a uma espécie de "marginalização involuntária"; não sendo "partidário" de nenhuma das correntes dominantes da poesia de sua época, chegou a declarar, em entrevista ao jornal O Globo, em 1993, que não se identificava nem como intelectual de esquerda, nem como concretista, para ele "duas igrejas cujos dogmas são insuportáveis" portanto, das "escolas" de pensamento de maior destaque, em matéria de poesia, no Brasil de 1960 e, consequentemente, de uma matriz de saber ao qual, inevitavelmente, essas "escolas" se filiavam, ou seja, a universidade, o saber institucionalizado, o poeta paulistano aponta para uma via de atuação que privilegia o saber livre, selvagem e, em último caso, orgíaco.

Em 1992, Roberto Piva escreve na coluna "Folhetim" do jornal Folha de São Paulo um texto intitulado "Todo poeta é marginal, desde que foi expulso da república de Platão". Nesse texto, cujo subtítulo é "O jogo gratuito da poesia", afirma:

O fazer poético passa pelo corpo e pela cama. "A poesia se faz na cama como o amor...", isto para começar a conversa. A palavra registrada em livro é a mera extensão (sublimada) do que sobrou da Orgia. Todos nós somos labaredas provocadas pelo curto-circuito do Desejo. O resto é balacobaco, isto é, literatura. Dante é pra ser relido numa sauna, rodeado de adolescentes. Não num escritório-abrigo-antiatômico. O vampirismo descobriu o desbunde, o marxismo e a linguagem caricata. Henri Michaux já deu o recado: Conhecimento através dos abismos. Inferno, Purgatório e Paraíso são uma coisa só. Mastigue cogumelos e Veja. Nenhuma regra: Ver com os olhos livres. Assim o curumim aprendeu o gosto de todos os espíritos. $\mathrm{O}$ assassinato também pode ser a ordem do dia. A blasfêmia e o roubo. Veja o episódio de Vanni Fucci no Inferno de Dante. Gíria da pesada de malandro medieval. Mimetismo. Para uma estética da crueldade. Como diz Edoardo Sanguinetti, "O Surrealismo é o fantasma que, com toda a justiça, persegue as vanguardas e thes nega um sono tranqüilo". Com a costela do Kapitalismo foi criada a Panacéia Socialista. O Forró Nuclear é a medida da Riqueza das Nações. As soluções em Poesia são individuais e não coletivas. Eu estou com 
Gilberto Vasconcelos: depois que joguei a obra completa de Marx pela janela, comecei a compreender o Brasil. Fora isto o seguinte: Poesia é uma forma de conhecimento que se vê através de objetos opacos, como uma viagem de LSD e estados mediúnicos de levitação. Xamanismo, linguagem da Sibila de Cumas e cantos de caça de povos "primitivos", poesia é uma atividade lúdica em que está empenhada sua vida, sua morte, a felicidade e principalmente o jogo. $\mathrm{O}$ jogo gratuito de todas as coisas. Por acaso, eis a origem de todas as coisas, diz Nietzsche. Não devemos excluir autoritariamente, como censor barato, nem os que se dizem marginais e não são e nem os que pensam que são marginais e são escriturários. Os Hitlers e Castros da vida já fizeram isso com muito mais eficiência. A Poesia é a mais fascinante orgia ao alcance do homem. E como diz Hegel, "A Orgia báquica da história será vivida por cada um de seus membros". ${ }^{44}$

O texto, escrito já na maturidade do poeta, revela uma preocupação em buscar "soluções poéticas" que, no caso, passam pela recusa em dobrar-se a um saber intelectualizado - jogar pela janela as obras completas de Marx é apenas um dos gestos indicativos dessa recusa - ao mesmo tempo em que localiza a "Poesia", em maiúscula, como forma de conhecimento primitiva, ritualizada e, da mesma forma, como atividade lúdica não excludente; portanto, não se deve dela excluir nem os marginais "verdadeiros", nem os "falsos" marginais.

Vanni Fucci, ladrão confesso de objetos sagrados de uma capela na catedral de Pisótia, um homem de "sangue e fúria" que, antes de se despedir de Dante, após ter feito uma nefasta profecia sobre o futuro dos "brancos" florentinos, faz um gesto obsceno para Deus, é eleito por Piva como "malandro medieval", gesto que o aproxima, a Piva, muito mais do malandro em questão do que do poeta, clara tomada de posição no já citado plano das suas "soluções poéticas". A negação do comunismo com o objetivo de "entender o Brasil", por outro lado, remonta à primeira poesia de Piva, que desde a "Ode a Fernando Pessoa", publicada em 1961, afirmava: "São Paulo, cidade minha, até quando serás convento do Brasil? / Até teus comunistas são mais puritanos do que padres" 45 , ou ao poema "A piedade", de Paranóia, publicado em 1963, em que afirma que "os comunistas são piedosos" ${ }^{46}$ da mesma forma que "as senhoras católicas são piedosas" ${ }^{47}$ e "os comerciantes são piedosos" ${ }^{48}$. Ou seja, que capitalismo - representado pelos comerciantes - e comunismo não são senão dois lados de uma mesma moeda, pensamento corroborado pelo manifesto publicado na Folha de São Paulo, em que se lê que "Com a costela do Kapitalismo foi criada a Panacéia Socialista". Assim mesclada, a tríade capitalismo-socialismo-cristianismo torna-se o inimigo a ser combatido, e não a alternativa - no caso do socialismo - a ser aceita e defendida.
44. PIVA, Roberto. Estranhos sinais de Saturno: obras reunidas volume 3, 2008, p. 187-188.
45. Idem. Um estrangeiro na legião: obras reunidas volume 1, 2005, p. 24.

46. Ibidem, p. 41.

47. Ibidem, p. 41.

48. Ibidem, p. 41. 
49. Ibidem, p. 41.

50. Ibidem, p. 66.

501dem, p. 80.
E ainda no poema "A piedade" dá-se o programa do combate, à medida em que o poeta afirma que apenas ele não é piedoso, e que "se eu fosse piedoso meu sexo seria dócil e só se ergueria aos / sábados à noite" ${ }^{\text {"49 }}$ e, mais ainda que isso, nunca poderá ser piedoso, pois ali onde se lê "meu sexo seria dócil" poder-se-ia perfeitamente ler "minha poesia seria dócil". A poesia, portanto, é a arma que o poeta traz para o campo de batalha e, assim sendo, não pode haver piedade.

Ainda em Paranóia, o "Poema porrada", à parte o eco ao "Poema em linha reta" de Fernando Pessoa, fortalece o tom combativo presente desde a primeira poesia de Piva: "Estou farto de muita coisa / não me transformarei em subúrbio / não serei uma válvula sonora / não serei paz / eu quero a destruição de tudo que é frágil: / cristãos fábricas palácios / juízes patrões e operários" $" 50$. Percebe-se a recusa pela conciliação entre os pretensos contrários, que devem, isto sim, ser destruídos para que, de suas ruínas, erija-se um mundo em cujo centro localizam-se a orgia e a festa, sob o signo de Dioniso. Isto porque, segundo anota Piva em "Homenagem ao marquês de Sade", de Piazzas, "falta ao mundo uma partitura ardente como o hímen / dos pesadelos" ${ }^{\prime}$, ou seja, falta ao mundo a energia erótica capaz de agredir a lógica burguesa-capitalista da vida.

Interessante apontar, à luz do que até o momento se apresentou, para o "Postfácio" de Piazzas, segundo livro de Piva, publicado originalmente em 1964, ano do golpe militar no Brasil. Nesse texto encontramos a faceta educadora do poeta, que apresenta certa metodologia presente na obra que escrevia ao longo dos anos 1960:

Assim a constatação de que Nietzsche estava certo \& lúcido ao afirmar que o homem moderno é uma mistura híbrida de planta \& fantasma, \& que as almas envenenadas pelo cristianismo se conformam \& glorificam as conveniências em nome de uma abdicação a favor de um Deus instalado na eternidade (projeção infantil da figura do Pai como confirmaria Freud) donde reparte suas Graças entre os homens mais consumidos de ressentimento, auto-flageladores \& submissos. As cavilosas maquinações contra a Vida como consequência de um Eu Ideal (Deus, Pai, Ditador) nos obrigando a renúncias instintivas, nos transformando em conflituados neuróticos sem possibilidades de Brecha alguma, reduzindo a vício o nosso espontâneo interesse pelo sexo, o cristianismo como a escola do Suicídio do Corpo revelou-se a grande Doença a ser extirpada do coração do Homem. Em todos os meus escritos procurei de uma forma blasfematória (Paranóia) ou numa contemplação além do bem \& do mal (Piazzas) a la Nietzsche explicitar minha revolta \& ajudar muitos a superar esta Tristeza Bíblica de todos nós, absortos num Paraíso Desumanizado, reprimido aqui \& agora. [...] Contra a inibição de consciência da 
Poesia Oficial Brasileira a serviço do instinto de morte (repressão), minha poesia sempre consistiu num verdadeiro ATO SEXUAL, isto é, numa AGRESSÃO cujo propósito é a mais íntima das uniões. ${ }^{52}$

Há ainda espaço para a denúncia:

Para a Sociedade Utilitarista do nosso tempo, a prova máxima de normalidade é a adaptação do indivíduo à família $\&$ à comunidade. Numa sociedade assim estruturada, todas as virtudes, digo Todas, estão a serviço do Princípio de Utilidade. Assim, entidades Policiais tipo Nazista como a R.U.D.I. ou a R.U.P.A. constituídas por criminosos fardados \& civis têm o poder absoluto para decidir quem é útil \& quem é inútil. Para os que ainda duvidam de que a nossa Sociedade é um Cárcere Criminoso, eu recomendaria que batessem um papo com qualquer adolescente egresso do R.P.M. (Recolhimento Provisório de Menores). Desta maneira, os nossos Ociosos literatos que lêem os terríveis relatórios das penitenciárias onde esteve Jean Genet teriam a imaginação suficiente para compreender que tudo que o genial Genet descreve nas inumeráveis prisões por onde passou acontece em termos mil vezes piores aqui no Brasil, São Paulo em 1964. Basta lembrar-nos que o Pau-de-Arara \& o choque elétrico pertencem ao folclore da Gestapo brasileira. ${ }^{53}$

E, por fim, a ruptura:

O que eu \& meus amigos pretendemos é o divórcio absoluto da nova geração dos valores destes neomedievalistas. E a libertação de si mesmos do Super-Ego da Sociedade. Isto é o que nos separa das filosofias autoritárias tais como elas aparecem nas têmperas conservadoras \& militaristas. Fazemos uma afirmação de que os atos individuais de violência são sempre preferidos à violência coletiva do Estado. [...] Sob o império ardente de vida do Princípio do Prazer, o homem, tal como na Grécia dionisíaca, deixará de ser artista para ser Obra de Arte..$^{54}$

Aqui podemos encontrar semelhanças entre o pensamento do Piva dos anos 1960 e o do Leminski dos anos 1970/1980, especialmente a partir de uma deflagração de luta contra o utilitarismo da sociedade capitalista.

Do primeiro volume das obras reunidas de Roberto Piva, publicadas entre 2005 e 2008 pela editora Globo ${ }^{55}$, constam quatro textos publicados por ele em 1962, quatro manifestos que, no livro, foram agrupados sob o título "Os que viram a carcaça". Os textos em questão são "O minotauro dos minutos", "Bules, bílis e bolas", "A máquina de matar o tempo" e "A catedral da desordem". A crer no que afirma o poeta no "Postfácio" de Piazzas, existe um cerne comum que, fantasmagoricamente, ronda a produção de seus dois primeiros livros
52. Ibidem, p. 128-129.

53. Ibidem, p. 130-131.

54. Ibidem, p. 131.

55. Não se trata de "obras completas". Ali não constam entrevistas, textos ou mesmo livros inéditos de Piva, à exceção de Estranhos sinais de Saturno.

Recentemente, Ibriela Sevilla defendeu tese de Doutorado na Universidade Federal de Santa Catarina em que apresenta a análise de dois livros inéditos do poeta, Coracões de hot-dog $\mathrm{e}$ Outdoor, a partir de pesquisa realizada em dois arquivos distintos, um deles localizado na cidade de São Paulo em posse do herdeiro dos direitos autorais de Piva, e outro guardado no Instituto Moreira Salles, no Rio de Janeiro, desde 2006. Cf. SEVILLA, 2015. Ibriela Bianca Berlanda. Todos os pivetes tem o men nome: imagens da subjetividade nos arquivos de Roberto Piva. Orientadora: Maria Lúcia de Barros Camargo. Florianópolis: Biblioteca Universitária, 2015. 
56. PÉCORA, Alcir. "Nota do organizador", 2008, p. 7.

57. Cf. LISTA, Giovanni. Arte e politica: Il futurismo di sinistra in Italia, 1980.

\section{Cf. GELADO, Viviane.}

Poéticas da transgressão: vanguarda e cultura popular nos anos 20 na América Latina, 2006. de poemas. Não poderia ser diferente no que diz respeito aos manifestos. Como afirma Alcir Pécora, o organizador das "Obras reunidas" do poeta,

Tal gênero de escritos, longe de ser apenas acréscimo supérfluo ao fundamental da poesia de Piva, revela uma forma de intervenção poética que ganha rara força nele. A rigor, não se distingue do lance decisivo de sua poesia: a interpelação arrebatada, voluntariosa, quando não irada, empreendida como política radical, isto é, agressiva, transgressiva, afetiva, anárquica, libertária, vigorosamente parcial, mas sempre anti-partidária e antiinstitucional. ${ }^{56}$

Assim entendidos, os textos escritos paralelamente aos livros de poemas, mimeografados ao longo dos anos 1960-1970, ou publicados em jornais e revistas a partir de 1990, são determinantes para a leitura da poesia de Piva, ao menos para aqueles que não consideram que poesia "evolui", mas que deve ser interpretada como um corpus em constante reelaboração. A escolha pela vertente manifestária, portanto, não é gratuita.

Um manifesto pode ser visto como uma forma didática de se apresentar o programa teórico e prático de determinada ideologia. Ele pode igualmente ser lido como uma carta, a correspondência de determinada corrente estética à sociedade, em que muitas vezes o projeto precede a obra de arte, tornando-se, por sua vez, um gênero discursivo que não só representa as premissas de uma nova estética artística, mas chega a quase assumir o lugar daquela mesma obra de arte que promete ${ }^{57}$. Em sua construção, que é fundamentalmente política - vide a obra de arte ataque das vanguardas históricas - o manifesto delineia aquilo que se pode compreender como a busca por uma identidade e, para o caso do Manifesto futurista escrito por Marinetti e publicado no Le Figaro em 20 de fevereiro de 1909, bem como do Manifesto dadaista escrito por Tristan Tzara em 1918, ou mesmo do Manifesto surrealista de Breton, escrito em 1924, e dos manifestos de Oswald de Andrade - Manifesto Pau-Brasil, publicado em O Correio da Manhã em 1924, e Manifesto Antropofágico, publicado na Revista de Antropofagia, em 1928 - embora haja neles referências e mesmo representações de movimentos artísticos anteriores, estes sempre são retratados a partir de um exercício que fundamenta as bases para uma crítica negativista ${ }^{58}$. Dessa forma, o manifesto artístico assumiria um status de obra de arte autônoma, ressignificando o passado ao mesmo tempo em que reivindica sua própria identidade. Roberto Piva, portanto, através da escrita de seus textos aparentemente não poéticos, busca não apenas a identidade e a identificação com seus possíveis leitores, mas igualmente a identidade de sua própria escritura, a qual insere, através do tom manifestário, em uma determinada 
corrente literária que o precede e à qual ele, por sua vez, reivindica e reescreve, o que faz transparecer o caráter moderno do manifesto, bem como sua perda de sentido atual.

As referências estão em toda parte na obra de Piva. Desde o poema de estreia, "Ode a Fernando Pessoa", passando por um cenário poético construído ao longo da vida do poeta e no qual figuram Mário de Andrade, Murilo Mendes, Jorge de Lima, Lautréamont, Sade, Augusto dos Anjos, Rimbaud, Artaud, Dante, Pasolini, Jacob Boehme e Darcy Ribeiro, apenas para firmar alguns nomes. De todo modo, não se trata de aceitar pacificamente a influência desse "paideuma"; não é senão a partir de ruínas, de restos, que ele surge.

De igual maneira são ressignificados os manifestos. Em "A catedral da desordem", último dos textos que compõem "Os que viram a carcaça", se lê: "Só a desordem nos une. Ceticamente, Barbaramente, Sexualmente" (PIVA, 2005, p. 141). Para além do eco ao Manifesto antropofágico, pode-se perceber que os vetores a serem combatidos e, portanto, a forma do combate, se modificaram. Se, no texto de Oswald, era a antropofagia o que nos unia como nação, no de Piva é a desordem que, justamente, poderá fazer com que superemos o ideal de nação, através da superação da castração erótica imposta ao Ocidente desde a aurora do domínio cristão.

Já na série de textos que compõem "O século XXI me dará razão", publicados no segundo volume das obras reunidas, interessa destacar uma espécie de transição no ideário do poeta, cuja maior consequência será a virada xamânica existente em seus últimos livros publicados, Ciclones, de 1997, e Estranhos sinais de Saturno, de 2008. Se nos textos dos anos 1960 a postura de guerra heroica se volta para a derrocada do "Kapitalismo" como causador da castração erótica, junto ao cristianismo, nos textos dos anos 1980, ao continuado tom demolidor da escrita, adere a criação de uma cosmogonia própria e que, previsivelmente, não deixa de ser maldita. Portanto, a reorganização do universo preside o "Manifesto utópico-ecológico em defesa da poesia \& do delírio", em cuja "Invocação" se lê:

Ao Grande deus Dagon de olhos de fogo; ao deus da vegetação Dionísio;

ao deus Puer, que hipnotiza o Universo com seu ânus de diamante;

ao deus Escorpião atravessando a cabeça do Anjo;

ao deus Lúper, que desafiou as galáxias roedoras;

a Baal, deus da pedra negra;

a Xangô, deus-caralho fecundador da Tempestade. ${ }^{59}$

Resumidamente, é possível perceber algumas das tópicas que mais preocuparam Piva ao longo de sua produção poética
59. PIVA, Roberto. Mala na mão e asas pretas: obras reunidas volume 2, 2006, p. 142. 
60. Ibidem, p. 128.

601 Ibidem, p. 144.

62. Ibidem, p. 144.

63. Ibidem, p. 144.

64. Cf. GOMBROWICZ, Witold. Contra os poetas, 1989.

65. Cf. PIGLIA, Ricardo. Teoria del complot, 2007. representadas pelas figuras que ilustram o texto. Dagon era o deus da fertilidade dos filisteus, culto que trouxeram da Babilônia. Também era o pai de Baal, divindade cananeia igualmente associada à fertilidade. O deus Puer é o Puer Aeternus latino, um deus-criança eternamente jovem, posteriormente retomado como arquétipo da Psicologia Analítica junguiana. Xangô, por sua vez, representa a força, a guerra, o poder arrebatador da tempestade. A fertilidade, aqui, é cultuada como força erótica dirigida à figura do menino, do adolescente eterno, representado, por exemplo, em Abra os olhos e diga Ah!, pelas figuras de Adriano e Antínoo, em Coxas pelos vários garotos que integram o grupo "osso \& liberdade", em 20 poemas com brócoli no "garoto negro" ou no "adolescente da lavanderia" e em Quizumba pelo sono dormido "entre os braços do menino que me deixa bêbado de Sonho"

A partir da invocação, o poeta pode então avançar para a defesa do direito humano ao pão e à poesia, como afirma, a partir de um plano político que, "em nome da saúde mental das novas gerações"'61, reivindica, dentre outras coisas, "Transformar a praça da Sé em horta coletiva \& pública" ${ }^{2}$ e "Distribuir obras dos poetas brasileiros entre os garotos (as) da Febem, únicos(as) capazes de transformar a violência \& angústia de suas almas em música das esferas" $" 33$.

Em 1947, Witold Gombrowicz, então exilado na Argentina, pronuncia, na livraria Fray Mocho, a conferência "Contra os poetas" $"$. Reunidos ali entusiastas da cultura e, naturalmente, da poesia, assistem horrorizados a um Gombrowicz que afirma, num espanhol impossível, que a poesia não existe, que não há nenhum elemento específico que possa determinar a um texto como sendo poético, senão o mesmo tipo de convenção compartilhada por aqueles que creem que um pedaço de papel com um número inscrito vale alguma coisa. A conferência de Gombrowicz, uma performance, na verdade, é uma das muitas estratégias elaboradas por ele a fim de promover a própria obra. No mesmo ano, 1947, seu Ferdydurke acabava de ser traduzido ao espanhol, e "Contra os poetas" vem para alicerçar ainda mais a seita de poucos admiradores que Gombrowicz mantinha na Buenos Aires de então. Assim, agindo como um conspirador, vai a uma livraria falar contra os poetas e sai, ainda por cima, empregado de um banco, pois o presidente do banco polaco assistia à conferência e lhe deu emprego. Dali, Gombrowicz trabalha sete anos como bancário, tempo em que vai redigir o seu Trasatlántico. Nesse contexto, a anedota se torna ainda mais espetacular: justamente a partir de uma conferência em que se defende que a poesia é uma convenção, como o dinheiro, sai dali um empregado de banco ${ }^{65}$.

No poema a seguir, Leminski assegura a falta de lugar do poeta no mundo: 
O pauloleminski

É um cachorro louco

Que deve ser morto

A pau a pedra

A fogo a pique

Senão é bem capaz

O filhodaputa

De fazer chover

Em nosso piquenique ${ }^{66}$

66. LEMINSKI, Paulo. Toda

poesia, 2013, p. 102.

Ao fim, o que interessa aqui é, de acordo com o "Manifesto da selva mais próxima", "Criar novas religiões, novas formas físicas, novos anti-sistemas políticos, novas formas de vida" ${ }^{67}$. Até porque, "No mais os leitores que fizeram uma boa síntese entre Poesia \& Vida terão grande oportunidade de se descobrirem nestes flashes" ${ }^{2}$, como afirma no "Postfácio" a 20 poemas com brócolis. Isto dito, a afirmação de Scramim, de que "a relação entre a poesia de Paulo Leminski e a poesia do final do século XIX se constrói e se mantém pelo desejo de produzir 'vida' literária em um contexto de 'morte"' ${ }^{69}$, pode ser igualmente aplicada a Piva. Dois poetas que compreenderam que a poesia é, antes de tudo, resistência.

\section{Referências}

AGAMBEN, Giorgio. Homo sacer: o poder soberano e a vida nua I. Tradução Henrique Búrigo. Belo Horizonte: Editora UFMG, 2002.

ALIGHIERI, Dante. A Divina Comédia: Inferno. Tradução Italo Eugênio Mauro. $1^{\mathrm{a}}$ ed. bilíngue. São Paulo: Editora 34, 1998.

ANDRADE, Carlos Drummond de. Alguma poesia. São Paulo: Companhia das Letras, 2013.

ANJOS, Augusto dos. Eu e outras poesias. Porto Alegre: L\&PM, 2010.

BATAILLE, Georges. A parte maldita - precedida de "A noção de dispêndio". Tradução de Júlio Castañon Guimarães. $2^{a}$ ed. revisada. Belo Horizonte: Autêntica Editora, 2013.

BAUDELAIRE, Charles. Le spleen de Paris. Nice: Édition du Groupe, 2003.

BÜRGER, Peter. Teoria da vanguarda. Tradução de José Pedro Antunes. São Paulo: Cosac \& Naify, 2012.
67. PIVA, Roberto. Mala na mão e asas pretas, 2006, p. 149.

68. Ibidem, p. 117.

69. SCRAMIM, Susana. "Paulo Leminski e o simbolismo", 2010, p. 220. 
CAMPOS, Augusto de; CAMPOS, Haroldo de; PIGNATARI, Décio. Noigandres 4. São Paulo: Edição dos autores, 1958.

COHN, Sérgio (org.). Encontros: Roberto Piva. Rio de Janeiro: Beco do Azougue, 2007.

FAUSTINO, Mário. "Revendo Jorge de Lima”. In: LIMA, Jorge. Invenção de Orfeu. São Paulo: Cosac \& Naify, 2013.

FRANCHETTI, Paulo. "Paulo Leminski e o haicai". In: SANDMANN, Marcelo (org.). A pau a pedra, a fogo a pique: dez estudos sobre a obra de Paulo Leminski. Curitiba: Imprensa Oficial, 2010.

GELADO, Viviane. Poéticas da transgressão: vanguarda e cultura popular nos anos 20 na América Latina. Rio de Janeiro: 7Letras; São Paulo: EdUFSCar. 2006.

HEIDEGGER, Martin. Caminos de bosque. Tradução Helena Cortés e Arturo Leyte. Madrid: Alianza Editorial, 2010.

HOLLANDA, Heloísa Buarque de. Impressões de viagem: CPC, vanguarda e desbunde 1960/70. Rio de Janeiro: Aeroplano, 2004.

LEMINSKI, Paulo. Catatau: um romance-ideia. Curitiba: Travessa dos Editores, 2004. . Ensaios e anseios cripticos. $2^{\mathrm{a}}$ ed. ampliada. Campinas: Editora da Unicamp, 2012. . Toda poesia. São Paulo: Companhia das Letras, 2013.

LISTA, Giovanni. Arte e politica: Il futurismo di sinistra in Italia. Milão: Edizioni Multhipla, 1980.

MARCUSE, Herbert. "Über den afirmativen Charakter der Kultur". In: . Kultur und Gesellschaft I. Frankfurt: Suhrkamp Verlag, 1968.

NETO, João Cabral de Melo. Prosa. Rio de Janeiro: Nova Fronteira, 1998.

PÉCORA, Alcir. “Nota do organizador”. In: PIVA, Roberto. Estranhos sinais de saturno: obras reunidas volume 3. São Paulo: Globo, 2008.

PIGLIA, Ricardo. Teoría del Complot. Buenos Aires: Mate, 2007. PIVA, Roberto. Estranhos sinais de Saturno: obras reunidas volume 3. São Paulo: Globo, 2008. - Mala na mão e asas pretas: obras reunidas volume 2. São Paulo: Globo, 2006. 
Um estrangeiro na legião: obras reunidas volume 1. São

Paulo: Globo, 2005.

POMPÉIA, Raul. “Glória Latente”. In: ARARIPE JÚNIOR, T. A. O Ateneu e o romance psicológico. Florianópolis: Cultura e Barbárie, 2013.

SCHILLER, Friedrich. Poesia ingênua e sentimental. Tradução Márcio Suzuki. São Paulo: Iluminuras, 1991.

SCRAMIM, Susana. "Paulo Leminski e o simbolismo". In: SANDMANN, Marcelo (org). A pau a pedra, a fogo a pique: dez estudos sobre a obra de Paulo Leminski. Curitiba: Imprensa Oficial, 2010.

SEVILLA, Ibriela Bianca Berlanda. Todos os pivetes tem o men nome: imagens da subjetividade nos arquivos de Roberto Piva. Orientadora: Maria Lúcia de Barros Camargo. Florianópolis: Biblioteca Universitária, 2015.

VAZ, Toninho. O bandido que sabia latim. Rio de Janeiro:

Record, 2001. 